\title{
Place and Role of Personnel Audit in Slovak companies in the Industrial Revolution Stage 4.0 and 5.0
}

\author{
Miroslava Szarková1,1 \\ ${ }^{1}$ Faculty of Business Management, Department of Management, University of Economics in \\ Bratislava, Dolnozemská cesta 1/b,852 35 Bratislava, Slovak republic
}

\begin{abstract}
The need to effectively use the intellectual and physical potential of human resources increased especially in the phase of the fourth industrial revolution 4.0 and the onset of the fifth industrial revolution 5.0. At these stages the quality of human resources as well as their effective management create a basis for the very existence of the company and at the same time represent a "hatchery" of employees for the future development and competitiveness of the company. In these developmental stages sophisticated information on human resources, their management and leadership as well as on possible reserves in personnel processes gain great importance. This information can be provided to corporate management by a personnel audit. Based on the results of primary and secondary research, the aim of the paper is to give an overview of the use of personnel audit in companies operating in the Slovak Republic. Keywords: personnel audit, human resources, human resources management, intellectual capital.
\end{abstract}

\section{Introduction}

Personnel audit is not only a highly actual but also quite complex topic and is not always viewed by corporate management in terms of perception of its need and usefulness, but rather perceived as a method whose results and findings force them to make changes in human resources and management, sometimes even changes that are unpleasant for them [1]. However, as recent developments show, often also necessary. They also force corporate management to learn to react/make decisions in the present with respect to the future of the company. Applying this "new" approach to corporate management means in all areas of company management to abandon established, often experience-based management methods $[2,3]$ and to learn to use sophisticated procedures and methods.

The use of personnel audits by company management is the result of developments in the labor market that have arisen as a result of the onset of the Industrial Revolution 4.0. It changed not only the entrepreneurial and business environment, but also the perception of personnel work, the positions and roles of employees in the work process and forced a change in the approach to their management. The field of personnel work, especially the perception of employees/staff of the company, was for a long time in theory and practice

${ }^{1}$ Corresponding author: miroslava.szarkova@euba.sk 
understood only as "complementary activity", which contained the basic maintenance of administrative processes in the personnel area. This understanding of personnel work was also fostered by the economic crisis, which multiplied the workforce on the labor market and multiplied the illusion of perception of the workforce through its number and not through differences, uniqueness and quality. However, the onset of the Fourth Industrial Revolution has shown that the administrative processes used so far in personnel work have been inefficient and ineffective in terms of the established company needs. For timecompliant decisions, corporate management needed sophisticated information about the workforce, its quality, mental, physical and performance potential [4] and the human resources simply did not have such information. This, as well as other moments related to the massive onset of information and communication technologies and the deepening globalization processes, created the conditions for the emergence of a personnel audit $[5,6]$.

Establishment and content definition of personnel audit reflected the need to obtain information on human resources in the company and on the application of basic legislative and administrative procedures in personnel work, personnel administration and finally in personnel management [7,8]. This basic characteristic is reflected in all definitions of personnel audit, which they define as a comprehensive tool both for monitoring and obtaining relevant information on compliance with legislative procedures in labor relations [9] and activities related to employment of people, with compulsory care of employees and with recruitment, storage and updating of personnel information and documents, as well as the provision of information to company directors and relevant institutions $[10,11,12]$. Its objective is to objectively describe the current state of society and to determine whether specific areas of personnel practice are sufficient and whether they comply with legal standards [13] and to identify and describe deviations that have arisen in this area [14-17 and others].

\section{Subject of the research and characteristics of the examined sample}

The subject of the submitted study is the personnel audit, its place and functions in the process of human resources creation and their effective management. The basis of the research is the main assumption that personnel managers, personnel departments, human resources departments, corporate management in companies operating in the Slovak Republic do not perceive personnel audit, its tasks and importance for improving human resources work and their management in the full range of currently offers them to streamline personnel work and personnel activities. Therefore, the main objective of secondary research was to systematize current knowledge about personnel audit and to find out in primary research whether companies operating in the Slovak Republic carry out personnel audit and whether they use the information obtained in it to improve the human resources of the company and their management.

The examined sample consisted of personnel managers and managers from small, medium and large companies with $100 \%$ Slovak capital participation operating in the SR, personnel managers and employees from the group of small and medium companies with $100 \%$ foreign capital participation operating in the SR and personnel managers and managers from a group of small and medium-sized companies with combined ownership. 445 companies were asked and the basic criterion for their inclusion in the next stage of the research was to carry out a personnel audit in the company or "other" forms or ways of obtaining data on human resources for the needs of the company personnel policy.

Based on the knowledge and information obtained in secondary research, we have found that "many managers cannot accurately identify a personnel audit", they cannot distinguish it from other human resource practices... (for example, the cost approach to human 
resources applied by as part of the accounting audit, also personnel controlling as pointed out by M. Dolenko, 1990 [14], R.M. Grant, 2008 [18] and others, we decided to conduct a pilot survey in order to clean up a sample of respondents who only believed that they performed the personnel audit they actually performed other personnel activities. For this purpose, a questionnaire was created, which was distributed electronically, in print form by post and also through third, contact persons in order to achieve the highest return. This objective was ultimately achieved.

The sample consisted of 160 companies, which were further subdivided according to the set criteria: size, number of employees, subject/sphere of business. One HR manager/personnel professional and two managers replied to the questionnaire from each company, giving a total of 480 questionnaires. These questionnaires were the main source of data to examine the identified issue. Due to the way the questionnaires were distributed, their $100 \%$ return was ensured. Standard quantitative and qualitative methods were used to collect, process, evaluate and interpret the data.

\section{Results of the Research and Discussion}

The aim of the primary research was to find out whether companies operating in the Slovak Republic use personnel audit to identify reserves in the area of human resources and their management. Within the partial goals, we also focused on the characteristics of companies operating in the Slovak Republic, which performed the personnel audit to obtain information on human resources, on the characteristics of companies operating in the Slovak Republic, which performed the personnel audit for information on human resources management and characteristics of companies operating in the Slovak Republic, which carry out personnel audit focused on managers managing and leading human resources in the direction of meeting the strategic objectives of the company, also referred to in the literature as managerial personnel audit $[19,20]$.

The results obtained through the application of these methods confirmed our assumption that within companies operating in the Slovak Republic the personnel audit is carried out mainly by medium-sized and large companies, companies with combined ownership participation, while the vast majority of companies proceed to personnel audit only or due to the employee complaints or threats of control by public authorities and institutions. Only a small number of companies $(2,1 \%)$ proceeded to conduct a personnel audit based on internal, in-house or corporate management needs. In most of the companies examined, a partial internal personnel audit was carried out, focusing on individual personnel activities, which in their entirety reflected the individual procedures applied in the area of human resources management. Most of them were occupational health and safety audits, which corresponded to the above. 


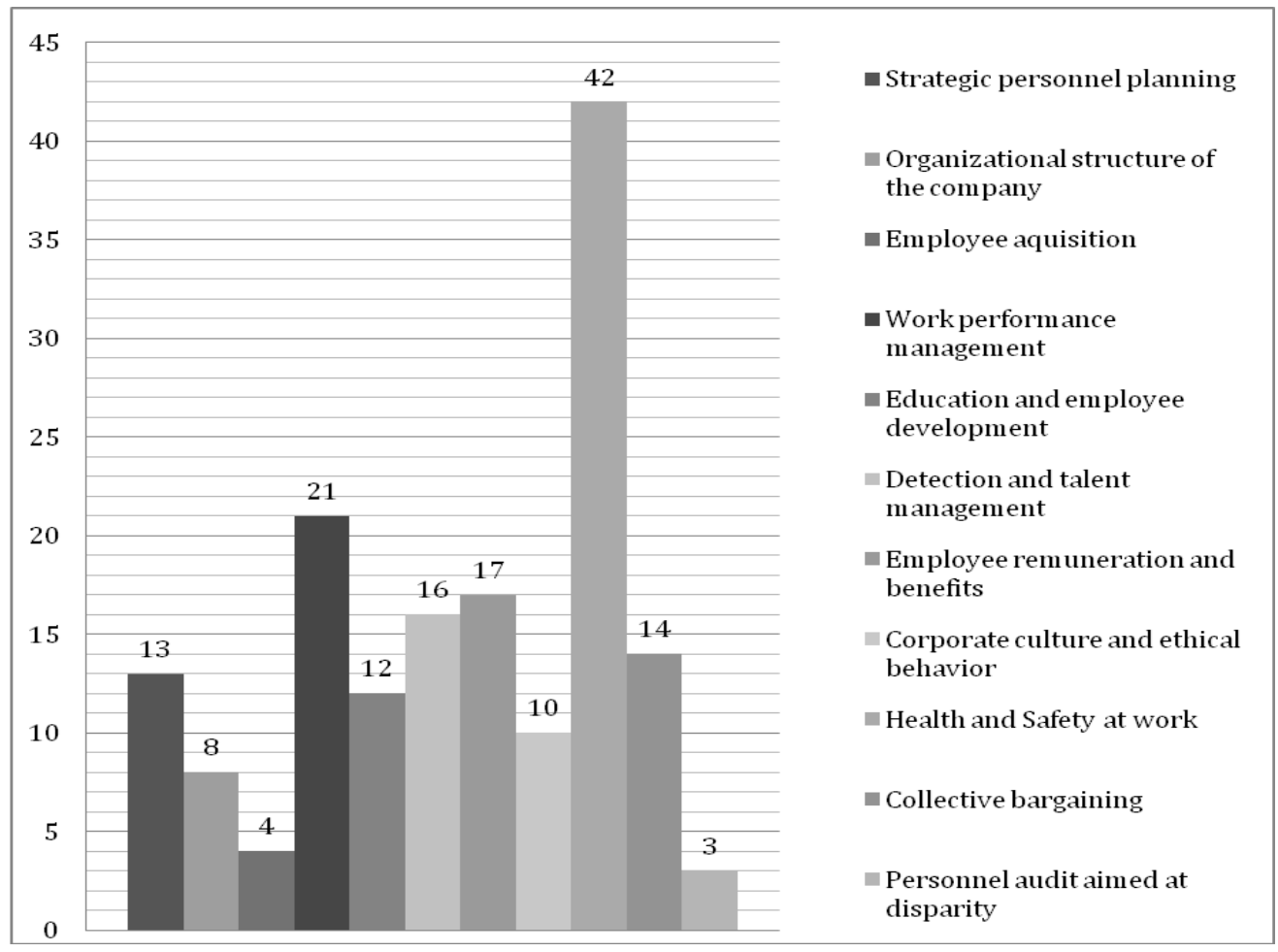

Fig. 1. Personnel activities monitored by personnel audit in examined companies (Source: own elaboration)

Human resources management companies performed partial audits mostly sporadically, which logically provided only a partial view of the company's problems and did not allow corporate management to gain a comprehensive view of the company as a whole. This moment was also reflected in a certain attitude of the company management towards the implementation of the obtained data into the personnel work in the company, respectively streamlining management processes in the company in accordance with the set standards. A more in-depth analysis of this issue provided information that the management of personnel and company managers persisted in learned work stereotypes and working habits, despite being found to be in violation of established standards and elements of effective human management based on findings in a personnel audit resources, respectively intellectual capital, including its individual components. This secondary finding, although very interesting and signaling one of the serious problems in human resources management, was obtained from the content analysis of responses obtained by the method of structured/controlled interviews of some of the examined respondents who did not represent the whole sample and in light of this, we consider this to be only a signal that indicates the direction of future research in the area. It was also a marginal, but in our opinion very interesting finding, that the companies examined conducted a personnel audit in the area of human resources management without a prior analysis of its implementation needs and without defining its objectives - these were defined by the auditor. In most cases, the auditor came from the company's internal environment. The purpose and reasons for conducting a personnel audit are interpreted in Figure 2. 


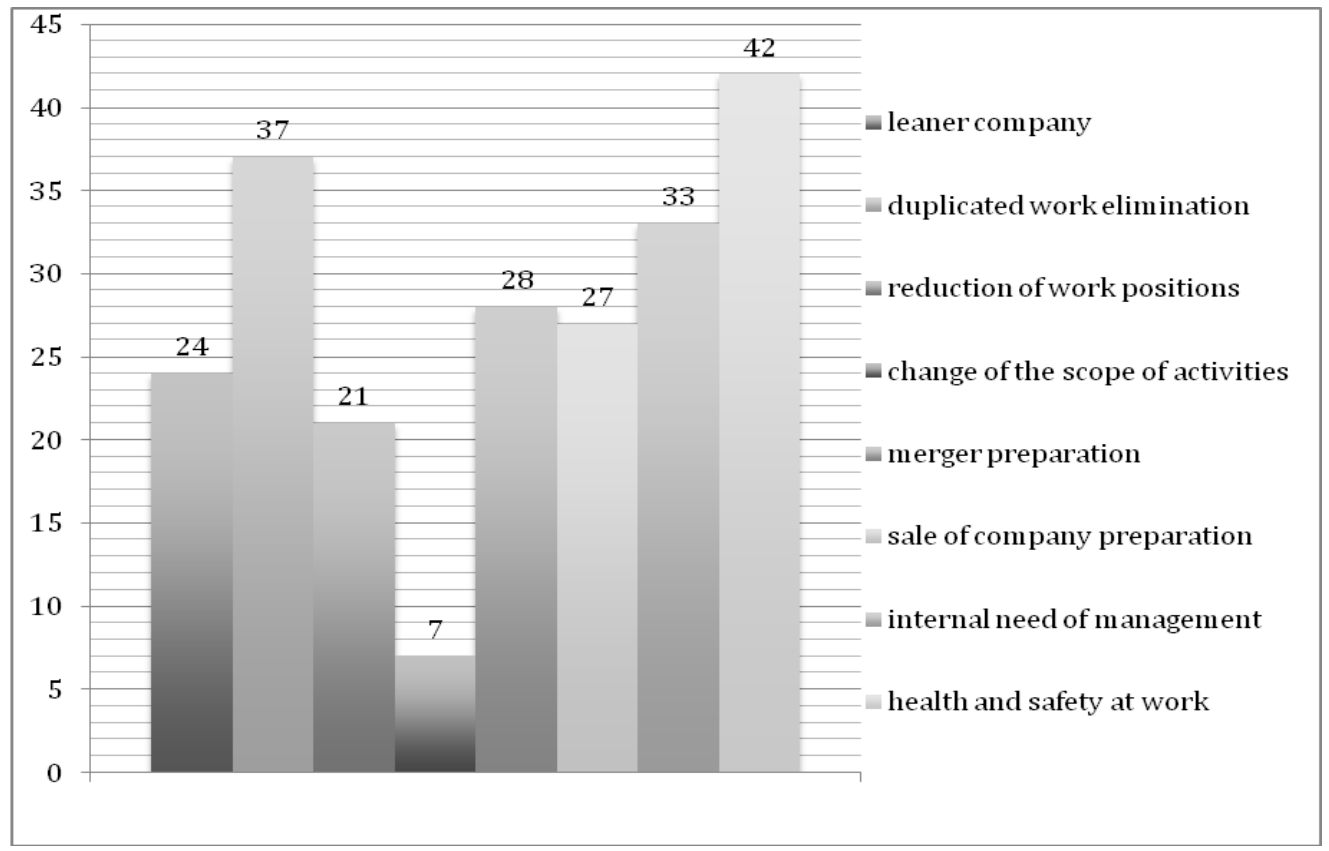

Fig. 2. Purposes/reasons/needs to perform a personnel audit in the company (Source: own elaboration)

The number of companies examined that carried out a human resources audit was less numerous. The data obtained in this area document that the personnel audit focused mainly on compliance to administrative procedures, legal standards and ethical principles resulting from established corporate standards and legislative provisions. Personnel audits focused on human resources were performed mainly by demanded companies that did not have personnel departments or those in which personnel, especially administrative activities, were delegated to human resources managers. The obtained findings entitle us to state that the companies that did not have personnel departments, resp. in which personnel managers have delegated their competencies to managers, have shown a higher number of errors and weaknesses in administrative and legal procedures in the area of human resources than companies with functional personnel departments.

\section{Conclusion}

Personnel audit, its place and function in the process of the deepening industrial revolution 4.0 and the upcoming revolution 5.0 are still growing. This is due to the fact that, when applied correctly, personnel audit can provide relevant and sophisticated information and knowledge necessary for strategic human resources management, which is becoming increasingly characteristic of the current phase of personnel work and personnel policy of companies. On the one hand, based on the knowledge gained from the personnel audit, the personnel department and the company management can eliminate incorrect procedures and remove the reserves in personnel work, both in the area of selection and training of employees and in the area of their management. The results obtained in the primary research document that companies operating in the Slovak Republic still do not sufficiently use personnel audit to obtain relevant information on personnel work in the company on the 
quality of the company's intellectual capital or on the reserves of management and leadership in the work process. However, the current trend suggests that personnel audit, which is an independent, objective, critical review of adherence to standard personnel practices in the company, collects data on people, processes, organizational structure and business principles, sets a benchmark for accurately determining the true performance of the human resources department to identify weaknesses in performance and efficiency and detect discrepancies in compliance with legal provisions, administrative procedures, ethical standards, business goals and personnel policy, will be one of the most important personnel work tools in the Industrial Revolution 5.0 stage. In this context, the personnel audit, which enables the company to obtain comprehensive information about the human resources of the company, its management as an essential component of its intangible assets, is undoubtedly a modern and comprehensive tool of personnel work.

The paper was created within the framework of the project VEGA 01/0309/18.

\section{References}

1. S. Nutley. Beyond systems: HRM audits in the public sector. Human Resource Management Journal, 2000, 10.2: 21-38. ISSN (2000)

2. S. Hlásna. Prognostické metódy v personálnom marketingu. In Personálny marketing a personálny manažment v organizácii: recenzovaný zborník vedeckých prác. Bratislava: EKONÓM. ISBN 978-80-225-3843-5, p. 17-21 (2013)

3. M. Rešovský, D. Pastor. Porovnanie metód priameho ohodnocovania nehmotných aktív. In: Ekonomické rozhl’ady, vol. 43, no. 4, p. 467 - 480. ISSN 0323-262X (2014)

4. M. Barteková, H. Majduchová 2019. Performance Potential and Development of Creative Industry: The Case of Slovakia. In 33rd International-Business-InformationManagement-Association (IBIMA) Conference (Granada, Spain, 5895-5902, 2019)

5. M.F. Olalla, A.S. Castillo. Human Resources Audit. In: International Advances in Economic Research. 2002, vol. 8, no. 1, p. 58 (2002)

6. R.K.Yadav, N. Dabhade. Human Resource Planning and Audit-a Case Study of HEG Limited. Human Resource Management. 4: 5 (2014)

7. M. Szarková, M. Andrejčák, N. Matkovčíková. Personnel audit as a function of personnel marketing and personnel management. Brno: Tribun EU, 2014. ISBN 978 80-263-0809-6 (2014)

8. M. Szarková. Psychológia pre manažérov. Praha: Wolters Kluwer, 2016. 260 s. ISBN978-80-7552-175-0 (2016)

9. N. Matkovčíková. Implementation of EU OSH Standards in companies operating in Slovakia. In Ekonomické rozhl'ady : vedecký časopis Ekonomickej univerzity v Bratislave. - Bratislava : Ekonomická univerzita v Bratislave, 2015. ISSN 0323-262X, 2015, vol. 44, no. 3, p. 314-322. VEGA 1/0662/15 (2015)

10. G.T. Milkovich, J.W. Boudreau. Ř́zení lidských zdrojú. ISBN 80-85623-29-3 (1993)

11. R.L Brummet, E.G. Flamhotz, W.C. Pyle. Human Resource Measurement: A challenge for accountants. The accounting Review, no.42, 1968.

12. P. Durai. Human Resource Management Dorling Kindersley (lndia) Pvt. Limited: Edition (2010). 
13. A. Clardy, A. The legal framework of human resources development (Part I). Human Resource Development Review, 2(1), p.26-53 (2004)

14. M. Dolenko. Auditing Human Resource Management. Florida: Institute of Internal Auditors Research Foundation (1990)

15. E.G Flamholz, Y. Randle. Future directions of Human Resource Management, Los Angeles, CA, University California p.369-90 (1996)

16. J.J. Phillips, J. J. Accountability in human resource management. Routledge, (1996)

17. R.L. Brady. Managing An HR Department of One. Old Saybrook: Business \& Legal Reports, inc. 2006. p. 47. ISBN 1-55645-184-9 (2006)

18. R.M Grant. Contemporary Strategic Analysis. Blackwell Publishing, 2008. p. 138. ISBN 978-1-4051-6309-5 (2008)

19. M. Vetráková, G. Bočincová. Human Resources Management. Banská Bystrica: Univerzita Mateja Bela v Banskej Bystrici. ISBN 978-80-557-0489-0 (2013)

20. J. Kintler. Eliminácia rizík spojených s investovaním do l'udského kapitálu podniku In: Personálny marketing a personálny manažment v organizácii. Bratislava: EKONÓM. ISBN 978-80-225-3843-5 (2013)

21. IAS 38 - The International Accounting Standard for Intangible Assets is a standard designed to recognize and measure intangible assets in the financial statements of companies. 